\title{
Hemodynamics alterations during orthotopic liver experimental transplantation in pigs ${ }^{1}$
}

\section{Alterações hemodinâmicas durante transplante hepático ortotópico experimental em suínos}

\begin{abstract}
Orlando Jorge Martins Torres', Patrícia Brandão Pantoja"I, Erica Sampaio Barbosa' ${ }^{\mathrm{II}}$, Cristiany de Almeida Barros" Elizabeth Teixeira Noguera Servin"II, Santiago Cirilo Noguera Servin ${ }^{\text {III }}$
\end{abstract}

${ }^{\text {I }} \mathrm{PhD}$, Associate Professor, Department of Surgery, Federal University of Maranhão (UFMA), Brazil.

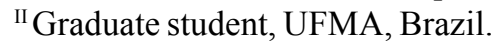

${ }^{\text {III }}$ Post-Graduate student, UFMA, Brazil.

\begin{abstract}
Purpose: To describe the hemodynamics alterations during orthotopic liver transplantation in pigs. Methods: In the period from April 2004 to December 2005, forty-four female Landrace pigs, weighting between 32 and $38 \mathrm{Kg}$ were undergone to orthotopic liver transplantation. The animals were divided into two groups, donor and recipient pairs, which received whole liver grafts. The surgical procedure was divided into four parts: harvested, back-table, hepatectomy of the recipient and implantation. We analyze heart rate, blood gas, mean systemic arterial pressure (MAP-mmHg), central venous pressure, $\mathrm{pH}, \mathrm{Na}^{-}, \mathrm{K}^{+}, \mathrm{Cl}^{-}, \mathrm{Ca}^{+}$and urinary output. Results: The mean anhepatic time was $69 \mathrm{~min}$, cold ischemia was $252.2 \mathrm{~min}$ and back-table was $56.6 \mathrm{~min}$. Blood pressure and heart rate dropped significantly during anhepatic phase and after revascularization. Blood gas and electrolytes alterations were observed during anhepatic and reperfusion phases. Although alterations were noted during these phases, the hemodynamic status was recovered and stabilized in the end of the surgery. Conclusions: Simplified technique of liver transplant was achieved and description of hemodynamic alterations was possible in pigs.
\end{abstract}

Key words: Liver Transplantation. Hemodynamic Phenomena. Swine.

\section{RESUMO}

Objetivo: Descrever as alterações hemodinâmicas que ocorrem durante o transplante hepático ortotópico experimental em suínos. Métodos: No período de abril de 2004 a dezembro de 2005, quarenta porcos da raça Landrace, fêmeas, pesando entre 32 e $38 \mathrm{Kg}$ foram submetidos a transplante hepático ortotópico. Os animais foram divididos em dois grupos, doador e receptor, estes receberam enxerto total. O procedimento cirúrgico foi dividido em captação, cirurgia de banco, hepatectomia do receptor e implante do enxerto. Analisamos a freqüência cardíaca, gasometria, pressão arterial média (PAM-mmHg), pressão venosa central, $\mathrm{pH}, \mathrm{Na}^{-}, \mathrm{K}^{+}, \mathrm{Cl}^{-}, \mathrm{Ca}^{+}$, e débito urinário. Resultados: $\mathrm{O}$ tempo médio de fase anepática foi de 69 minutos, tempo de isquemia fria foi de 252,2 minutos e cirurgia de banco de 56,6 minutos. A pressão sanguínea caiu significativamente e a freqüência cardíaca elevou-se durante a fase anepática e de revascularização. As alterações na gasometria e eletrólitos foram observadas durante as fases anepática e de revascularização. Embora estas alterações tenham sido observadas durante aquelas fases, o padrão hemodinâmico foi recuperado e estabilizado no final da operação. Conclusões: Uma técnica simplificada de transplante hepático experimental teve seu objetivo alcançado e foi possível identificar corrigir as alterações hemodinâmicas encontradas em suínos.

Descritores: Transplante de Fígado. Fenômenos Hemodinâmicos. Suínos.

1. Research performed at Department of Surgery, Experimental Research, Federal University of Maranhão (UFMA), Brazil. 


\section{Introduction}

Liver transplantation has become the major treatment for end-stage chronic liver disease and for severe acute liver failure, because of improvements in surgical techniques and development of more powerful immunosuppressive agents. Developments in liver transplantation have depended on research in small and large animals. Considerable interest in experimental liver transplantation has been generated recently due to improvements in the results of clinical liver transplantation efforts $1,2,3,10,11,19,21$. Prior to human liver transplantations, exhaustive training is undertaken on an animal model in order to acquire the expertise required for this delicate procedure. The pig has considerable anatomic similarities to man, as well as a comparable physiological and hemodynamic sensitivity. The technique of a liver transplant the pig has two advantages, it provides an excellent training model of liver transplantation, and an experimental model for research. Experimental orthotopic liver transplantation is a technically complex procedure which requires meticulous attention to anesthesia, preoperative and postoperative care and many other details to achieve consistently high survival rates. The pig has been used for experimental liver transplantation and as a model by our experimental team to perfect our clinical liver transplantation technique. These procedures are crucial factors in studies involving experimental liver transplantation in the pig to prevent unacceptably high morbidity and mortality in the transplant recipients $7,8,9,21$. The aim of this study is to describe the hemodynamics alterations during orthotopic liver transplantation in pigs.

\section{Methods}

Forty-four young female Landrace pigs, weighting between 32 and $38 \mathrm{Kg}$ (mean $34.2 \mathrm{Kg}$ ) were subjected to experimental protocol. The animals were divided into two groups, donor and recipient pairs. The recipients were undergone to orthotopic liver transplantation, and received whole liver graft. Animals were kept under standard laboratory conditions and fasted for 24 hours before surgery. All operations were carried out under general anesthesia and performed according to the international principles for research on animals under the supervision of a veterinary, which set the guidelines to minimize the suffering of the animals.

Pigs were pretreated with ketamine hydrochloride, diazepam and fentanyl. Animals were then intubated and ventilated by intermittent positive pressure with a mixture of oxygen and air. The animals were operated in neurolept anesthesia. After premedication and induction, fentanyl and pancuronium were administered as a continuous infusion until hepatectomy was completed.

The right carotid artery was cannulated in the recipient for measurement of mean systemic arterial pressure and for systemic arterial sampling. The left external jugular vein was used for the porto-iliac-jugular shunt and the right external jugular vein was cannulated for measurement of central venous pressure and for transfusion purposes.

The surgical procedure was divided into four parts: harvested, back-table, hepatectomy of the recipient and implantation.

For donor and recipient operations, we used a midline laparotomy. In the donor operation, portal vein, infrahepatic vena cava (IHVC) and suprahepatic vena cava (SHVC) were dissected out. The hepatic artery was kept in continuity with the celiac trunk and abdominal aorta up to the iliac bifurcation. In situ cold liver perfusion (with Euro Collins ${ }^{\circledR}$ and Ringer's lactate solutions) was then performed through both portal vein and aorta. The harvested graft was immersed in a plastic bag filled with Euro Collins ${ }^{\circledR}$ perfusion solution at $4^{\circ} \mathrm{C}$ and put in a basin and it was underwent for back-table procedure. The veno-venous bypass was used in some animals during the anhepatic phase (Figure 1).

After total hepatectomy in the recipient, the graft was put in place and suprahepatic vena cava and portal vein were sutured. After completion of both venous sutures, the liver graft was reperfused. The infrahepatic vena cava was then anastomosed and unclamped. The hepatic artery was done. The biliary reconstruction consisted of a cholecysto-duodenostomy.

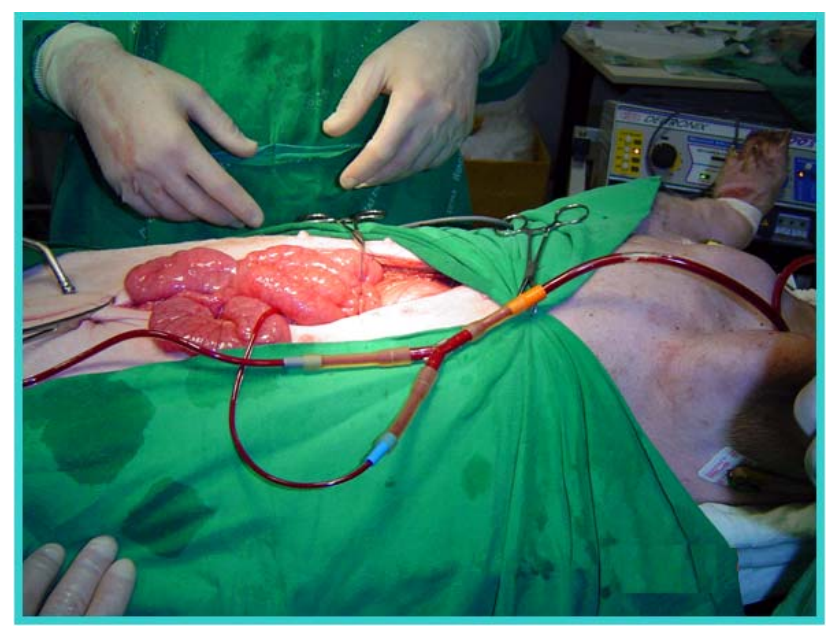

FIGURE 1 - Veno-venous by-pass during anhepatic phase

Hemodynamic and metabolic changes during the procedure were monitored. The following parameters were recorded during the surgery in preanhepatic phase, anhepatic phase and after revascularization with restoration of the blood flow to the heart: heart rate (HR), Blood gas analysis $\left(\mathrm{CO}_{2}-\mathrm{mmHg}\right),\left(\mathrm{HCO}_{3}-\mathrm{mmol} / \mathrm{L}\right)$, basic excess value $(\mathrm{mmol} / \mathrm{L})$; Mean systemic arterial pressure (MAP-mmHg), central venous pressure $\left(\mathrm{CVP}-\mathrm{cmH}_{2} \mathrm{O}\right), \mathrm{pH}, \mathrm{Na}^{-}, \mathrm{K}^{+}, \mathrm{Cl}^{-}, \mathrm{Ca}^{+}$ and urinary output were performed at regular intervals.

\section{Results}

There was just one death before closure of abdominal wall (recipient) with operative mortality of $4.5 \%$. The cause of death was anesthesia problems. 
The use of a veno-venous iliac-portal-jugular bypass without use of a biopump and with moderate systemic heparinisation during the anhepatic phase was performed in eight pigs. Ten were undergone to liver transplantation without venous bypass. In the non-bypass group the supracoeliac aortic was clamped during the anhepatic phase. The mean time in each procedure was represented in Table 1 , and the time spent to perform the anastomosis is represented in Table 2.

TABLE 1 - Mean time in each phase of the procedure

\begin{tabular}{lccccc}
\hline Phase & Perfusion & Back-table & Cold ischemia & Anhepatic phase & Recipient time \\
Mean time $(\mathrm{min})$ & 18.2 & 56.6 & 252.2 & 69.0 & 184.3 \\
\hline
\end{tabular}

TABLE 2 - Mean time to perform the anastomosis

\begin{tabular}{llllll}
\hline Anastomosis & SHVC & PV & IHVC & HA & BD \\
Mean time (min) & 16.07 & 16.14 & 19.8 & 17.7 & 6.22 \\
\hline
\end{tabular}

SHVC: Suprahepatic vena cava

PV: Portal vein

IHVC: Infrahepatic vena cava

HA: Hepatic artery

BD: Bile duct

The hemodynamic and gasometrical data were analyzed in three different moments (Tables 3 to 5):

TABLE 3 - Clinical parameters in the recipients

\begin{tabular}{lllll}
\hline Hemodynamic & MAP & SO & HR & CVP \\
Pre anhepatic & 95.3 & 100 & 101.1 & 8.8 \\
Anhepatic & 85.4 & 95.2 & 119.8 & 9 \\
Reperfusion & 29.3 & 92.5 & 76 & 10 \\
\hline
\end{tabular}

MAP: Mean systemic arterial pressure

$\mathrm{SO}_{2}$ : O2 Saturation

HR: Heart rate

CVP: Central Venous Pressure

TABLE 4 - Blood gas analysis in the recipients

\begin{tabular}{llllll}
\hline Blood gas & $\mathbf{p H}$ & $\mathbf{p O}_{\mathbf{2}}$ & $\mathbf{H C O}_{\mathbf{3}}$ & $\mathbf{B E}$ & $\mathbf{p C O}_{\mathbf{2}}$ \\
Pre anhepatic & 7.37 & 169 & 25.9 & -2.2 & 49 \\
Anhepatic & 7.26 & 234 & 22.9 & -4.1 & 51 \\
Reperfusion & 7.28 & 194 & 17.0 & -9.9 & 44.7 \\
\hline
\end{tabular}

BE: Base excess

TABLE 5 - Serum electrolytes in the recipients

\begin{tabular}{lllll}
\hline Electrolytes & $\mathbf{N a}^{-}(\mathbf{m E q} / \mathbf{l})$ & $\left.\mathbf{K}^{+} \mathbf{m E q} / \mathbf{l}\right)$ & $\mathbf{C l}^{-} \mathbf{~ m E g} / \mathbf{l}$ & $\mathbf{C a}^{+}(\mathbf{m m o l} / \mathbf{l})$ \\
Pre anhepatic & 150 & 3.6 & 100 & 1.2 \\
Anhepatic & 174.2 & 5.0 & 153.5 & 1.19 \\
Reperfusion & 158.6 & 4.1 & 132.3 & 1.71 \\
\hline
\end{tabular}




\section{Discussion}

Only recently, in our laboratory of experimental surgery, we started with a protocol for orthotopic liver transplantation in a pig model. This was felt as mandatory for experimental purposes as well as for future clinical applications at our center. Our model also allowed us to undertake some physiological studies during the transplantation procedure. This technique is not only similar to the procedure applied to man, but it also provides a safe and reproducible experimental model ${ }^{4,5,12,16,21}$. The aim of the study was to monitor metabolic changes in the liver graft over time during transplantation in a pig model. We point out the importance of experimental surgery to reach a human program and the need for implementing research in transplantation program with coordination of all centers in order to have the best and appropriate outcome ${ }^{3,4,5,6,21}$.

Numerous surgical techniques have been developed that permit the investigator to carry out studies with high clinical relevance. This model provides us security and quickness, we spend about six hours and we obtain results comparable to other authors. Almost all twenty-two transplanted animals survived at least until the abdominal wound closure. One animal died during the operation, possibly due to anesthesia problems $4,5,13,14,28$. The surgery in the donor was satisfactory, but the cold ischemia time was relatively long. The time spends to perform the suprahepatic vena cava and portal vein anastomosis was short resulting in a satisfactory anhepatic phase. The others anastomosis were done after revascularization.

Although liver transplantation in larger laboratory animals such as dogs and pigs is technically easier, liver transplantation in rats is frequently used as a transplantation model. In dogs, however are much more resistant to this procedure, and for ethical reasons, will not be available in the future for experimental settings $7,8,12,22,24,25,28$.

Preservation of liver function after the cold storage period can be accomplished by complying with several key steps during the procurement. Keep the procedure short, provide extensive exposure, allow only minimal dissection, irrigate the portal system through the splenic vein and thereby obtain regular blood flow through the organ up to the clamping point, and ice the liver abruptly in situ. This retrieval technique was used in our experiment. The method allowed short and successful organ procurement 9,26,27,26,28.

Blood pressure and heart rate dropped significantly during anhepatic phase and after revascularization. In pigs, vascular clamping induced a significant decline of cardiac output. However, after the release of vascular clamping the blood pressure dropped significantly lower than during vascular clamping. After cold perfusion, some levels increased, whereas others levels decreased rapidly. During implantation of the liver graft, some levels showed an accelerated increase. After portal reperfusion, they decreased and finally settled at normal levels. At this time, some levels increased, with a peak after reperfusion, and then decreased to normal levels. During rewarming, it showed an accelerated increase, but after reperfusion, it decreased rapidly. Rewarming and reperfusion are most harmful to the liver, reflected by an accelerated increase in glucose. After revascularization, none of these variables differed significantly between groups, and levels of electrolytes were getting better after transplantation. Metabolic acidosis should be avoided by administration of sodium bicarbonate before declamping and corrections of alterations in serum electrolytes. These above-mentioned observations have led to a safe anesthetic procedure and management in experimental orthotopic liver transplantation 4,5,6,7,17,20,25,27.

The pig tolerates simultaneous clamping of the liver pedicle and inferior vena cava poorly, so veno-venous bypass can be used during the anhepatic phase of experimental orthotopic liver transplantation. The transplant without veno-venous bypass, leads to severe hemodynamic disturbances. Oxygen delivery dropped below the critical level and flow-dependent oxygen consumption developed during the anhepatic phase without venous bypass. In this case the other procedure is clamping of the supracoeliac aorta during the anhepatic phase to allow transplantation in stable hemodynamic conditions. So it may prove to be a useful technique in liver transplantation in animals, such as dogs or pigs. Some authors reported porcine liver transplantation without the use of veno-venous bypass by adopting a temporary aortic occlusion technique to prevent severe hypotension during the anhepatic phase. Comparable 24-hr survival (72\%) was reported as well, in groups with or without veno-venous bypass. Although such technique is attractive, Gruttadauria et al ${ }^{7}$ demonstrated that anhepatic phase without venovenous could be easily tolerated during a $30-\mathrm{min}$ period, which is usually sufficient to perform the two venous sutures preceding graft revascularization. Clamping of the supracoeliac aorta produced a significant liver injury compared with the control group $4,5,6,8,13,15,16,17,18,28$.

\section{Conclusion}

Simplified technique of liver transplant was achieved and description of hemodynamic alterations was possible in pigs.

\section{References}

1. Bacchella T, Machado MCC. The first clinical liver transplantation of Brazil revisited. Transplant Proc. 2004; 36: 929-30.

2. Busuttil RW, Tanaka K. The utility of marginal donors in liver transplantation. Liver Transplant. 2003; 9; 651-63.

3. De Lange JJ, Hoitsma HF, Meijer S. Anaesthetic management in experimental orthotopic liver transplantation in the pig. Eur Surg Res. 1984; 16:360-5.

4. Eisele PH, Woodle ES, Hunter GC, Talken L, Ward RE. Anesthetic, preoperative and postoperative considerations for liver transplantation in swine. Lab Anim Sci. 1986; 36: 402-5.

5. Falcini F, Martini E, Marsili M, Benassai C, Fabbri LP, Tanini R, Linden M, Simoncini R, Filipponi F, Cataliotti L. Veno-venous bypass in experimental liver transplantation: portal-jugular versus cavalportal-jugular. G Chir. 1990;11:206-10. 
6. Filipponi F, Falcini F, Benassai C, Martini E. Orthotopic liver transplant in pigs: several variations of the surgical technique. G Chir. 1989;10:374-8.

7. Gruttadauria,S Marino G, Catalano F, Sgroi AV, Di Mauro GL, Basile F. Porcine orthotopic liver auto transplantation: facilitated technique. J Invest Surg. 2001; 14: 79-82.

8. Hojo, N, Ishibashi T, Yasuda T, Sakuma Y, Fujiwara T, Kawarasaki H, Nagai H- Porcine model for surgical training of living related liver transplantation, Transplant Proc. 2003; 35: 82-4.

9. Keeffe EB- Liver transplantation: current status and novel approaches to liver replacement. Gastroenterology. 2001; 120:749-62.

10. Laino GM, Anastasi A, Fabbri LP, Gandini E, Valanzano R, Fontanari P, Venneri F, Mazzoni P, Ieri A, Spini S, Scalzi E, Batignani G. Trapianto di fegato sperimentale nel maiale. Minerva Chir. 1996; 51:765-72.

11. Lopez-Santamaria M, Migliazza L, Gamez M, Murcia J, Paz Cruz JA, Munoz J, Canser E, Qi B, Lobato R, Diaz M, Tovar JA- Supraceliac aortic clamping during the anhepatic phase of experimental orthotopic liver transplantation.. J Pediatr Surg. 1999; 34:1374-7.

12. Martinez-Ibanez V, Margarit-Creixell O, Boix-Ochoa A. A new experimental model of liver transplant in pigs. An Esp Pediatr. 1987;26:107-10.

13. Miao X, Zhao H, Qi H. The model of piggyback orthotopic liver transplantation in pigs. HunanYi Ke Da XueXue Bao. 1999; 24:77-9.

14. Mizrahi SS, Jones JW, Bentley FR A facilitated technique for hepatectomy of porcine liver. J Invest Surg. 1996;9:393-8.

15. Nowak G, Ungerstedt J, Wernerman J, Ungerstedt U, Ericzon BG. Metabolic changes in the liver graft monitored continuously with microdialysis during liver transplantation in a pig model. Liver Transplant. 2002;8:424-32.

16. Oike F, Uryuhara K, Otsuda M, Dehoux JP, Otte JB, Lerut J, Gianello P- Simplified technique of orthotopic liver transplantation in pigs. Transplantation. 2001; 71: 328-31.

17. Oldhafer KJ, Schuttler W, Hauss J, Spiegel HU, Pichlmayr R- Analysis of hepatic hemodynamics after orthotopic liver transplantation: an experimental study in pigs. Transplant Proc. 1993; 25:2599.
18. Regueira FM, Espy A, Nwose P, Dyez-Caballero A, Baixauli J, Rotellar F, Olea J, Pardo F, Herna JL, Cienfuegos JA. Comparison between two warm ischemic models in experimental liver transplantation in pigs. Transplant Proc.2003; 35: 1591-3.

19. Rela M, Agarwal A- Liver transplantation. J Gastroenterol Hepatol 2002; 17:294-297.

20. Spiegel HU, Palmes D. Surgical techniques of orthotopic rat liver transplantation. J Invest Surg. 1998;11:83-96.

21. Starzl T, Marchioro TL, Von Kaulla KN, Hermann G, Brittain RS, Waddel WR - Homotransplantation of the liver in humans. Surg Gynecol Obstet. 1963; 117:659-76.

22. Steinig, D Mentha G, Lecoultre C, Pittet JF, Jeanjacquot A, Huber O, Meyer P, Rohner AExperimental porcine orthotopic liver transplantation: a training protocol for transplantation in humans. Helv Chir Acta. 1990; 57:177-86.

23. Takahashi T. Experimental study on orthotopic liver transplantation using veno-venous bypass in the pig - the evaluation of hemodynamic alterations and the estimation of appropriate bypass flow during the period of the anhepatic state. Hokkaido Igaku Zasshi. 1987;62:616-28.

24. Tanaka K, Nishimura A, Ogata S, Yoshimine M, Ikoma A, Taira A- A simple method for liver transplantation in pigs. Transplantation. 1994; 58: 1139-42.

24. Tang GJ, Shann TY, Lu HC, Lin BS, Lui WY, Chan KH, Lee TY, Peng FK Peri-anhepatic phase oxygen kinetics in porcine liver transplantation. Zhonghua Yi Xue Za Zhi. 1999;62:285-93.

25. Taniguchi H, Takada K, Fukunaga K, Yuzawa M, Otsuka K, Todoroki F. Establishment of a swine model for auxiliary partial orthotopic liver transplantation. Transplant Proc. 1998; 30: 3232-6.

26. Van AS AB, Lotz Z, Tyler M, Adams S, Ryffel B, Kahn D- Histological assessment after different methods of reperfusion following liver transplantation. S Afr J Surg. 2002; 40 :95-8.

27. Woodle ES, Hunter GC, Eisele P, Talken L, Ward RE. Orthotopic porcine liver transplantation: operative technique. J Surg Res. 1985; 39 :483-8.

\section{Correspondence:}

Prof. Orlando Torres

Rua dos Bicudos, 14/600

Ed. Aspen Renascença II

65075-090 São Luís-MA Brazil

o.torres@uol.com.br
Conflict of interest: none Financial source: none

Received: September 18, 2007

Review: November 20, 2007

Accepted: December 11, 2007

\section{How to cite this article}

Torres OJM, Pantoja PB, Barbosa ES, Barros CA, Servin ETN, Servin SCN. Hemodynamics alterations during orthotopic liver experimental transplantation in pigs. Acta Cir Bras. [serial on the Internet] $2008 \mathrm{Mar}-\mathrm{Apr}$;23(2). Available from URL: http://www.scielo.br/acb 